\title{
Emerging Entrepreneurial Universities in University Reforms: The moderating role of personalities and the social/economic environment
}

JózSEF BERÁCS ${ }^{1}$

$\propto$ University education, research and other services are increasingly becoming private goods as opposed to the traditional public goods concept. This trend is a highly debated process, and its consequences for universities are unquestionable. One of the consequences may be the diffusion of entrepreneurship in the higher education sector. The aim of the present paper is to highlight some of the characteristics of this process. Starting with the classics of entrepreneurship literature, Schumpeter defined the entrepreneur as somebody who goes against the stream. A new combination of production factors is the soul of entrepreneurship, and of any changes such as university reforms. Earlier research by Clark shed light on the environment of emerging entrepreneurial universities, which happened to be mainly new, relatively small universities. He found five indicators that are components of entrepreneurial universities. Taking this concept as a point of departure, we extended it in two directions. First, we go back to the economics literature and collect several other indicators/statements about entrepreneurship that are also worth considering in higher education. Second, we present a number of successful entrepreneurial cases of large top universities, looking for other indicators. Summarising these indicators in a table, two reforms of the Corvinus University of Budapest and its predecessors are discussed. Both of the reform processes lasted about five years, and there was a gap of approximately 20 years between the two processes. We would expect this to be successful, as a university needs to be reformed every 20 years, but this was not the case. We come to the surprising conclusion that, at least in case of the Corvinus University of Budapest, the two reforms in the socialist period were more entrepreneurial than the reforms we are experiencing now in a market economy environment. The explanation for this situation is twofold: the general socioeconomic environment is not really supportive of reform initiatives, and there is a lack of charismatic leadership.

Keywords: the entrepreneurial university, university reforms, leadership, the socioeconomic situation, Corvinus University of Budapest 


\section{Univerzitetne reforme in nastajanje podjetniških univerz. Usmerjevalna vloga osebnosti in socialno- ekonomskega okolja}

JózSEF BERÁCS

$\propto$ Univerzitetno izobraževanje, raziskovanje in druge storitve vedno bolj postajajo zasebne dobrine $\mathrm{v}$ nasprotju s tradicionalnim konceptom javnega dobrega. O tem trendu se veliko govori, posledice za univerze pa so nesporne. Ena izmed njih je lahko širjenje podjetništva v visokošolski sektor. V prispevku osvetlimo nekaj značilnosti tega procesa. Začnemo s klasiki literature o podjetništvu: Schumpeter je definiral podjetnika kot nekoga, ki gre proti toku. Bistvo podjetništva je nova kombinacija proizvodnih dejavnikov in tako je tudi pri vseh drugih spremembah, npr. pri univerzitetnih reformah. Clarkove predhodne raziskave so osvetlile okolje, v katerem nastajajo podjetniške univerze - večinoma nove, sorazmerno majhne univerze. Kot komponente podjetniških univerz je identificiral pet kazalnikov. Ta koncept smo vzeli za osnovo in ga nadgradili v dveh smereh. Prvič: znova smo analizirali ekonomsko literaturo in zbrali še druge kazalnike/postavke o podjetništvu, ki jih je vredno upoštevati tudi v visokem šolstvu. Drugič: predstavimo nekaj uspešnih podjetniških primerov večjih vrhunskih univerz, pri čemer skušamo najti še druge kazalnike. Potem ko vse te kazalnike združimo v preglednici, analiziramo dve reformi Univerze Corvinus v Budimpešti oziroma njenih predhodnic. Oba reformna procesa sta trajala okoli pet let, med njima pa je minilo približno 20 let. Pričakovali bi, da sta bila procesa uspešna, ker se univerza vsakih 20 let mora reformirati, vendar to ni bilo tako. Presenetljivo tudi ugotovimo, vsaj ko gre za Univerzo Corvinus v Budimpešti, da sta bili reformi, ki sta potekali v socializmu, bolj podjetniško naravnani kot reforme, ki potekajo zdaj, v okolju tržnega gospodarstva. Razlaga za to je dvojna: splošno socialno-ekonomsko okolje dejansko ne podpira reformnih pobud; obstaja pa tudi pomanjkanje karizmatičnega vodstva.

Ključne besede: podjetniška univerza, univerzitetne reforme, vodenje, socialno-ekonomski položaj, Univerza Corvinus v Budimpešti 


\section{Introduction}

Typologies of universities help university leaders and government policymakers to reflect on the positioning of their institutions and offer useful patterns for scientific analysis. Clark (1998) created three categories of universities: economic, entrepreneurial and service oriented. He identified a number of characteristics of each form, introducing five case studies representing the entrepreneurial spirit. Following this line of research, Hrubos (2004) discussed the archetype of the "economic university", which includes most Hungarian universities, where the macro level under-financing of universities is a continuous challenge for university leaders. In most post-communist countries, especially in Central and South-Eastern Europe, the marketisation of the entire economy after the collapse of the political system in 1989 became a natural endeavour. Following the trend of American higher education, strengthening the corporate culture (Gould, 2003) seemed to be a reasonable development in university reforms as well. According to many studies, however, this debated direction has only had a limited effect in former socialist countries (Zgaga, 2003; Hrubos, 2004; Vlasceanu \& Hansean, 2012; Pantic, 2012).

The distinction between public or private goods in higher education is a crucial point regarding the acceptance of any business-type approach in the education industry. For many people, even in the United States, the corporate or business philosophy is unacceptable in a higher education environment, especially in liberal arts studies (Gould, 2003). In the global world, however, especially for small countries, the existence of the market-oriented "entrepreneurial university" may become an important factor for developing the entire higher education system (Nagy \& Berács, 2012). Institutional and national higher education reforms, as well as quality improvements, are the key terms for policymakers and strategists to change traditional higher education systems, where education is thought to be part of public goods. The focus on the adoption of the Bologna Process in the last decade has diverted university leaders' attention away from the aforementioned subjects, where education is considered to be part of private rather than public goods. The aim of the present paper is to change the discourse and think about the roots of the competitiveness of emerging economies in higher education as a business potential focusing on entrepreneurship.

First, we analyse the relationship between economic development and entrepreneurship from historical perspectives. Second, market orientation and entrepreneurial orientation is discussed. Third, the main characteristics of entrepreneurial universities are highlighted. Fourth, some prestigious universities 
with an entrepreneurial spirit, from leading Western countries and from Hungary, are presented. Finally, two historical reforms of the predecessors of the Corvinus University of Budapest (CUB), undertaken in 1968-1973 and 19881993 are analysed and compared with recent developments (the Bologna Process 2006-2013). We draw the conclusion that, in order to better understand the reform process, the general social, economic, political and legal systems should be analysed, in parallel with the personal capabilities and core competencies of university leaders.

\section{Economic development and entrepreneurship}

The collapse of the communist regimes in Europe could be explained by many factors, but the distinction between bureaucratic and market coordination always played an important role. The market system of capitalism had superior economic growth potential compared to the planning and direct bureaucratic control of socialist systems (Kornai, 1992). The driving force behind the economic development of capitalism is its higher innovation capability, entrepreneurship and institutional systems. These concepts need to be analysed again and again in traditional capitalist societies and especially in transition economies. Some thoughts of three influential thinkers of the $2 \mathrm{O}^{\text {th }}$ Century (Schumpeter, Drucker, Coase) are highlighted, which facilitate an understanding of the higher education industry's shift from mainly public (socialist) systems towards more market-oriented (private, capitalist) systems. Although these distinctions might be stereotypes emerging from former socialist, Eastern European countries, and need more detailed justification in another paper, they are still dominant in thinking.

The father of the innovation theory, Austrian Joseph Schumpeter, researched the theory of economic development and found that innovation plays an important explanatory role. The development could be defined as a new combination of many factors, including products, markets (selling and purchasing), technologies, production processes, organisation, etc., but the key actor in this process is the entrepreneur. The question is: Who is the entrepreneur? Answering this question is not, however, an easy task. It could be a capitalist, a manager, an agent or any other stakeholder. An entrepreneur is somebody who is not an average person, who goes against the stream, who is looking for NEW solutions (Schumpeter, 1968). Schumpeter defines entrepreneurship as a new combination of production factors. As early as in the 1920s, he made an important distinction between exchange and collective economies. The distribution of goods and the control of processes in the exchange economy is performed 
by persuading power, while in the collective economy it is undertaken by commanding power. This kind of differentiation will be used later for the characterisation of university leadership.

The father of management theory, Austrian Peter Drucker, the most influential management guru of the last century, made a thorough analysis of innovation and entrepreneurship. His theoretical and practical overview covered the long history of capitalist development, and he had keen insights into numerous industries in Europe and the United States. Based on numerous examples, he concluded that sometimes big and old companies are real entrepreneurships (e.g., McDonalds and General Electric Company), and it is not only small companies that can be labelled by this term. Turning his attention to higher education, he compared the German (Humboldtian) universities of the $19^{\text {th }}$ century with the American universities of the $20^{\text {th }}$ century. Both were modern universities with similar curricula but operating in different markets. The top universities in both countries followed the rule "to be the fastest with the best". This principle characterises many innovative ventures, successful companies, institutions and universities (Drucker, 1985). Humboldt and the founders of American universities showed a deep understanding of the whole society and the dominant trends.

In his brief but highly influential essay entitled The Nature of the Firm, Coase (1937) attempts to explain why the economy features a number of business firms instead of consisting exclusively of a multitude of independent, selfemployed people who contract with one another. Given that "production could be carried on without any organization [that is, firms] at all", Coase asks why and under what conditions we should expect firms to emerge. The answer to this question was worth a Nobel Prize for economics many decades later. Since modern firms can only emerge when an entrepreneur of some sort begins to hire people, Coase's analysis proceeds by considering the conditions under which it makes sense for an entrepreneur to seek hired help instead of contracting out a particular task. Transaction cost analysis helps us to understand the corporate culture in higher education industry as well.

\section{Market orientation and entrepreneurial orientation as driving forces for economic growth}

Market orientation seemed to be the natural and dominant logic of companies in market economies, but it was not. Hence a new research stream (becoming the mainstream) rose in 1990 with the assistance of the Marketing Science Institute in the United States. New, valid measures of market orientation were developed, and their positive effect on business performance was 
proved. Market orientation was defined, on the one hand, as a construct of three components: customer orientation, competitor orientation and inter-functional coordination; on the other hand, it was defined as a composition of three sets of activities: (1) the organisation-wide generation of market intelligence pertaining to current and future customer needs, (2) dissemination of this intelligence across departments, and (3) organisation-wide responsiveness to it. These constructs have also been tested in higher education (Hammond, Webster \& Harmon, 2006; Nagy \& Berács, 2012). The models of market orientation consist of many antecedents (e.g., top management emphasis, reward systems, conflict resolution, etc.) and consequences (e.g., organisational performance, customer loyalty, quality, innovativeness, job satisfaction, etc.).

Like many other orientations, market orientation is a micro, institutional category, but its consequences can be measured in the macro level as well. We assume that increasing revenues of companies and institutions (in a profitable way) will result in higher GDP, that is, in higher macro output of the economy. There are two basic approaches to revenue growth: organic (internal) and external (mergers and acquisitions). In a meta-analysis of the determinants of organic sales growth, Bahadir et al. (2009) found that the degree of innovation, advertising, market orientation, inter-organisational networks, entrepreneurial orientation and managerial capacity are positive drivers of organic growth. Focusing only on entrepreneurial orientation, it consists of three components: innovativeness, proactiveness and a propensity to take risks. A higher level of entrepreneurship leads to higher investments in new businesses.

Both market orientation and entrepreneurial orientation are dependent on the general environment. Environment-focused determinants of growth can be grouped into three areas. First, according to the industrial organisation (I-O) theory, competition or competitive intensity explains firm growth largely based on industry structure. The firm's organic growth primarily depends on industry characteristics and how the company positions itself vis-à-vis industry structure. Second, munificence, one of the most commonly discussed environmental dimensions, should be taken into consideration. Munificence is defined as the availability of environmental resources to support growth; for example, a firm will achieve a higher growth rate in an industry with an abundance of credit, with government or EU funds, as opposed to in an industry where such financial assets are unavailable. Third, environmental dynamism refers to volatility and instability in an industry. Firms in a highly dynamic environment are less able to achieve high growth rates. Environmental complexity demands heterogeneous activities from companies, which can be based on managerial capacity relying on experience and teamwork (Bahadir et al., 2009). 


\section{Entrepreneurial universities: principles based on cases}

One of the founders of higher education research, Burton R. Clark, suggests that in order to understand the phenomena of the higher education sector one must analyse the role of three power-centres ruling universities. In his basic scheme, the academic oligarchy (the scientific community), the state bureaucracy (education governance) and market influence are the explaining indicators of university systems. Prior to 1990, these indicators were represented by the three dominant models of higher education: the traditional British system, where academic oligarchs have the power (no competition, no state control); the continental European model, where the state controls and finances (no competition); and the American model, where market competition is the most important indicator and state control is limited (Clark, 1983; Hrubos, 2006). Comparing these constructs with Kornai's description of the socialist system, the continental European model fits the socialist model perfectly, while the American model fits the capitalist system. The British model is somewhere in the middle, where the academic oligarchs in top universities like Oxford and Cambridge can create a competitive environment and market success as well.

Clark (1998) thoroughly analysed the universities where he believed that the entrepreneurial spirit dominated the governance of the university and led to great successes. Interestingly, the universities that served as excellent examples of entrepreneurship were mainly small universities, sometimes in remote places. The five cases (Warwick in England, Strathclyde in Scotland, Twente in The Netherlands, Chalmers in Sweden, Joensuu in Finland) offered a good opportunity for Clark to summarise five components of entrepreneurial universities: 1. strong and professional management: the top management plays an important role in infrastructure development, creating new business values, rearranging the distribution of income and taking strategic decisions;

2. establishing peripheries for development: efficient matrix-organisation and project orientation lead to founding industrial and business parks;

3. diversified financing: beyond teaching-based income, second and third sources of financing appeared, providing a good background for university autonomy;

4. strong, stimulating academic background: better conditions for research were created, there was no need to reduce successful activities;

5. entrepreneurial culture, permeating the whole university: all of the employees, all individuals, have an entrepreneurial working habit without any upper-level pressure. 


\section{Prestigious universities with an entrepreneurial spirit}

Even though the case studies used in Clark's (1998) research were mainly small, new universities, large institutions can create similar entrepreneurial situations, as Drucker (1985) highlighted. The following four universities from England, the United States and Hungary show partial or full determination towards entrepreneurship. These universities are not talking about reforms - at least this is not the main point - but in hindsight the observer can put together a picture that shows that the institute has been through substantial changes and has created something new. In the present paper, we use these universities as cases in order to illustrate major movements.

The market economy background itself does not offer sufficient motivation for leaders to create a system where elite and mass higher education can be combined. In England, the power of academic oligarchs, controlled by Margaret Thatcher in the 1980s, was restricted, which caused certain problems (the shift towards an entrepreneurial direction observed at the universities in Warrick and Strathclyde occurred as a result of these pressures.) Taking Oxford University as a case study, Nelles and Vorley (2008) illustrates that entrepreneurial architecture can be created in an elite environment as well, in contrast to Clark's (1998) cases. Without losing the relevance of teaching and research excellence as the two basic missions of universities, the "Third Mission" has become synonymous with commercialising academic research in the UK. Through the Higher Education Funding Council for England (HEFCE), government policy regularly measures the results of the knowledge/technology transfer agenda and financially supports the institutions involved, such as Oxford University. Oxford follows a holistic approach to realising the third mission. The university is located in a $12,000 \mathrm{~m}^{2}$ science park, hosting 60 firms. The intellectual capacity of the university is assigned to research services, which are funded by the government, charities and industries. Over a period of ten years (1997-2007), ISIS Innovation, one of the key players of the entrepreneurial architecture of Oxford, showed spectacular results: staff increased from 3 to 37 , open projects from 168 to 841 , license deals from 4 to 56 , new spin-outs from 1 to 7 , and consultancy from 34 to 89 . These figures represent another world from that which the reader might expect from a traditional world leader prestigious university like Oxford or Cambridge.

The University of Nottingham has always been a top university in terms of the internationalisation of their English campus, recruiting many foreign students from all over the world, especially from Asia. At a time when other countries were becoming more active in terms of international student recruitment, 
it became clear that UK institutions would need to be innovative if they wanted to continue attracting high quality students and staff. As with many other services, higher education was/is fundamentally geographically bound. However, this situation has changed significantly in the past two decades, thanks to such pioneering universities as Nottingham University. The delivery of specific degree programmes through international partnerships (programme mobility) has increased dramatically, but the idea of an international campus, a physical presence abroad, has created revolutionary changes. Nottingham University established the Malaysian campus in 2000 and the Chinese campus in 2004, its two flagship ventures, and became the world leader in this category (Ennew \& Fujia, 2009). Beyond the growth imperative of the university, strong leadership and a clear vision played a key role in the implementation of the programme. In 2013, there were nearly 10,000 students studying in these international campuses, and one third of them were foreign (not Malaysian or Chinese) students (Christine Ennew, deputy vice-chancellor of the Nottingham University and provost of the Malaysian campus, verbal presentation at a conference organised by the Centre for International Higher Education Studies at the Corvinus University of Budapest, 30 January 2014.) Many countries were positioning themselves as educational hubs (e.g., Singapore) and Malaysia had an ambition to be a major higher education destination by 2020. This coincided with the ideas of the Nottingham University. A quite different motivation of the local and federal Chinese institutions and their ambitions led to the establishment of the Chinese campus in Ningbo. The real revolutionary entrepreneurship was summarised by Christine Ennew in the following way:

"Making the decision is only half of the battle: implementation remains a major challenge. The Nottingham approach was to stress the idea of "one University, multiple campuses". What this meant in practice was that the Malaysian campus (and subsequently the campus in China) had to be full and integral parts of the University of Nottingham, in terms of the quality and standards associated with teaching, the broader student experience and an orientation to research excellence. In short, the campuses that Nottingham was to develop were not just teaching outposts (they were not just "branches") they were functionally equivalent campuses."

Stanford University is one of the top universities in California producing students and attracting professors who know a lot about technology, and they produce the knowledge and research that leads to the creation of companies. Silicon Valley became a successful "periphery for development" (to use Clark's term of 1998) for Stanford as well, where failure is not unthinkable, and where there is an abundance of venture capital. One of its founding fathers, Pitch 
Johnson, said: "The first thing you look for in an entrepreneur is a sense of integrity, honesty, openness and decency. The second thing is: Do they have a clear vision of the marketplace they want to serve?" (Stanford Business, Spring 2013, p. 13). These entrepreneurial features are characteristic of the Stanford Graduate Business School (GSB) as well. The top school, where Nobel Prize-winning economists, business people and management professors follow each other in the dean's office, is ready to reinvent itself. Garth Saloner, the last dean of the Business School, declares that reinventing management education is a work in progress. In the last six years, they have undertaken two major initiatives. In 2007, they improved student engagement by reforming the MBA curriculum, which introduced a more personalised curriculum combined with greater experiential learning. The second transformational project was the development of a new physical space to match their curriculum. The Knight Management Center, completed in 2010, combines an intimate classroom environment and modern technology with a centre that promotes multidisciplinary collaboration. In addition to these two milestones, the GSB is excelling in the use of magic experiential educational technologies for distance education, including massive online open courses (MOOC), in order to disseminate their rich faculty expertise beyond the walls of Stanford (Saloner, 2013).

The Hungarian Royal University of Debrecen was established in 1912, more than a hundred years ago. Due to the political, social and regional changes in the last century, it has undergone many transformations, disintegrations and name changes. The present University of Debrecen was created in 2000 in the second largest city of Hungary, Debrecen. Three independent universities and colleges merged to create a real "universitas" again, representing many disciplines, ranging from medical sciences to agricultural disciplines, in 24 faculties. In a city of just 200,000 inhabitants, the 30,000 students, including almost 4,000 foreign students, have a strong presence in everyday life. The university excels in many areas, e.g., in research grants coming from the European Union, in the third mission of the university establishing enduring relationships with the business sector, and, above all, in strong cooperation with the city. The latter plays an important role in hosting foreign students as well. Internationalisation is one of the key areas of the university, and in the last ten years it has tripled the number of foreign degree-credit students, becoming the leading university in Hungary in terms of the number of foreign students. Most of these students, who come from more than 80 countries, study medical sciences in tuition feebased English language programmes. The university has built up an extensive international agent network, regularly attending international student fairs and undertaking ongoing, efficient recruiting activities. The entrepreneurial spirit is 
reflected in professional management and diversified financing. The traditional underfinancing of Hungarian universities and the negative demographic trend could offer only lower quality education and research, whereas the revenue generated from foreign students makes it possible to preserve the quality of basic activities, to realise infrastructure investments, and to financially motivate administrative and academic staff (Fábián, 2012).

\section{University reforms and entrepreneurship at the Corvinus University of Budapest}

The above examples of successful universities show that traditional top universities follow the rules of the entrepreneurial ethos in one or more areas of their activities. This section summarises the principles and experiences of entrepreneurship and market orientation, and applies them to a historical evaluation of two of three university reforms of the Corvinus University of Budapest and its predecessors over the last 45 years. The aim of the analysis is to compare the development of entrepreneurship at the Corvinus University of Budapest to the reform processes.

University-level education in economics and commerce commenced in Hungary in 1920, when a new Faculty of Economics was established at the Royal Hungarian University. Since that time, the name of the university to which the faculty belongs has changed six times. In 1948, following the systems of other socialist countries, an independent Economics University was established, which took the name of Karl Marx in 1953. After the changes in political system, it was renamed the Budapest University of Economic Sciences (BUES) in 1990. In 2000, as a consequence of the first merger with the Public Administration College, the name was extended to the Budapest University of Economic Sciences and Public Administration (BUESPA). The present name, the Corvinus University of Budapest (CUB) was accepted in 2004, when the once independent Horticultural University merged with the BUESPA. The university had two emblematic reform periods: $1968-1973$ and 1988-93. Twenty years later, the period 2008-2013 would also have been a reform period, but unfortunately it was not declared as such, and, according to our own observations and university documents, it was not in fact a reform period, despite the fact that there were many changes due to the Bologna Process and the new government of 2010, as well as the new higher education law that came into force on 1 January 2012.

At this point, we set a research question: Do these reforms and the present situation fit the entrepreneurship indicators as summarised above? The first column of Table 1 summarises the main indicators of entrepreneurship 
derived from the literature review above. These indicators consist of 14 items, and conceptually represent different aspects of entrepreneurship. The first three groups of items come from the reviews of Shumpeter, Drucker and CoaseGould, and the fourth group consists of five items created by Clark. Two further items are derived from the market-orientation literature that is also relevant to entrepreneurial orientation, while the last item raises the basic question as to whether higher education can be considered to be primarily a part of public or private goods. Given that the answer is generally mixed, we look at the financing of higher education in the period concerned from the university perspective. Columns 2-4 of Table 1 illustrate the selected three periods of CUB faculties of economics, business and social sciences, with the present campus in Pest (or, in Hungarian, the "Közgáz" faculties). It is important to focus only on these faculties in order to maintain the relevance of historical comparison. The cells of the table contain expert judgments of the author, who happened to be a participant in all of the reform periods as a student, a professor, a head of institutions, a member of faculty councils, university senates and special committees responsible for changes, and, in the last six years, a higher education researcher as well. The items of the scales are elaborated and judged by the author as an expert, and will be developed later. 
Table 1. Indicators of entrepreneurial universities and their presence in three periods of the Corvinus University of Budapest (faculties of economics, business and social sciences).

\begin{tabular}{|c|c|c|c|}
\hline Indicators of entrepreneurship & $\begin{array}{l}\text { Reform period } \\
1968-1973\end{array}$ & $\begin{array}{l}\text { Reform period } \\
1988-1993\end{array}$ & $\begin{array}{l}\text { "Would have been" } \\
\text { reform period } \\
2008-2013\end{array}$ \\
\hline $\begin{array}{l}\text { 1/a. Goes against the stream, not } \\
\text { average }\end{array}$ & $\begin{array}{l}\text { New curriculum, } \\
\text { new technology, } \\
\text { mixture of initia- } \\
\text { tives }\end{array}$ & $\begin{array}{l}\text { New, US-based } \\
\text { system, bottom } \\
\text { up }\end{array}$ & $\begin{array}{l}\text { Continuation of the } \\
\text { Bologna Process, } \\
\text { top-down }\end{array}$ \\
\hline $\begin{array}{l}\text { b. Commanding versus per- } \\
\text { suading power is dominant }\end{array}$ & $\begin{array}{l}\text { Commanding } \\
\text { power }\end{array}$ & $\begin{array}{l}\text { Persuading } \\
\text { power }\end{array}$ & $\begin{array}{l}\text { Central power is } \\
\text { missing }\end{array}$ \\
\hline $\begin{array}{l}\text { 2/a. Follows the principle of "to } \\
\text { be the fastest with the best" }\end{array}$ & Partially & Totally & Partially \\
\hline $\begin{array}{l}\text { b. Relative size of the university, } \\
\text { market share }\end{array}$ & $\begin{array}{l}\text { Monopolistic situ- } \\
\text { ation }\end{array}$ & $\begin{array}{l}\text { Duopolistic situ- } \\
\text { ation }\end{array}$ & $\begin{array}{l}\text { Oligopolistic situ- } \\
\text { ation, many small } \\
\text { competitors }\end{array}$ \\
\hline 3/a. Begins to hire people & Modest & Intensive & Recession \\
\hline b. Corporate, business culture & Partially & Strong intention & Hesitation \\
\hline $\begin{array}{l}\text { 4/a. Strong and professional } \\
\text { management }\end{array}$ & Partial & Full & Partial \\
\hline $\begin{array}{l}\text { b. Establishing peripheries for } \\
\text { development }\end{array}$ & Not relevant & Strong & Not relevant \\
\hline c. Diversified financing & Initiatives & Expressed wish & Passive use \\
\hline $\begin{array}{l}\text { d. Strong, stimulating academic } \\
\text { background }\end{array}$ & Initiatives & First priority & Lip service \\
\hline $\begin{array}{l}\text { e. Entrepreneurial culture, per- } \\
\text { meating the whole university }\end{array}$ & Partial & General & Sporadic \\
\hline 5/a. Customer/student orientation & Starting ideas & $\begin{array}{l}\text { Problem ori- } \\
\text { ented }\end{array}$ & $\begin{array}{l}\text { Part of quality as- } \\
\text { surance }\end{array}$ \\
\hline $\begin{array}{l}\text { b. Competitor orientation, rank- } \\
\text { ing }\end{array}$ & Not relevant & Second priority & $\begin{array}{l}\text { Formally yes, con- } \\
\text { tent-wise limited }\end{array}$ \\
\hline 6/ Is HE public or private good? & Public & Dominant public & Public and private \\
\hline
\end{tabular}

The content of each of the 42 cells $(14 \times 3)$ will not be discussed individually, but together this content attempts to give an impression of the whole reform, or "would be reform" process from an entrepreneurial perspective. Our aim is to characterise the socioeconomic, political context of each period and highlight the managerial capacity of the university. The first reform occurred in the period of the communist system, trying to serve a more efficient economic system. The rector of the university, Kálmán Szabó, had a vision of university reform, and even of reform of the political-economic system, as a member of parliament. The second reform started in the communist period, as is well documented (Csáki \& Zalai, 1987), and finished in the free market economy. The rector of the university, Csaba Csáki, had international experience visiting top universities such as Stanford in the US. Both reforms were initiated by 
ambitious, conceptually dedicated and enthusiastic leaders, who were trying to catch up with the best global universities (Shin at al., 2011). Even in the environment of the command socialist economy, they were aware of the barriers to the system, and they used the entrepreneurial, innovative concepts described by Schumpeter $(1926,1968)$. Forty years after the first reform, the latest period of 2008-2013 was headed by two rectors, and, on the background of a great deal of turmoil, there were no signs of a real reform process. By definition, reform means some kind of entrepreneurship, as Schumpeter proposed. We will review each of the periods below.

Before 1968, advocates of the superiority of the socialist/communist system as opposed to the capitalist system in Central Europe lost a belief in the idea that this was the best system of mankind. A relatively open discussion commenced regarding an "economic mechanism" (a new term discussed extensively in Kornai, 1992) to reform the socialist economic system, and to combine the command (planned) economy with a market economy. The Karl Marx University of Economic Sciences, the only university in Hungary offering masters and $\mathrm{PhD}$ (at that time, university doctorate) degrees in economics and business, was at the centre of developing the economic reform. The rector, a political scientist and ideologist, built a parallel reform process in the university, in order to fulfil the needs of the new economy with knowledgeable graduates. A new curriculum was developed, where management, marketing and strategic subjects became an organic part of education. Case methods and simulation games helped the students to become familiar with the modern market economy. The Ford Foundation helped the university to send dozens of young assistants and associate professors to top US universities (Harvard, Stanford, Chicago, etc.) as visiting scholars for one year. These academics returned with a modern knowledge of economics and business. Both students and professors were enthusiastic about reforming education and research, and the Ford Foundation grant was a generous donation, a market-based reward for talented young academics. Education technology changed with the introduction of concentrated periods, where the students could choose subjects for month-long intensive study. The commanding power, coupled with an innovative and entrepreneurial spirit, resulted in efficient university management, relying on solid finances.

As we have learned from Drucker (1985), top universities follow the rule "to be the fastest with the best", which characterised mainly the second reform period in 1988-1993. At the end of the 1980s, Central European citizens were aware that the socialist system as it was could not compete with the world. The new leadership of the Karl Marx University of Economic Sciences, a new generation educated and researched in the West, found the political system sufficiently 
tolerant to reform Marxist economic education, creating a new curriculum offering bachelor and masters degrees. In a nutshell, the university was ahead of its time fulfilling many of the requirements of the Bologna Process, which were launched officially 16 years later in Hungary. The rector and vice-rector managed to convince many of the academics that the time was right for change (Zalai \& Csáki, 1987). Relying on persuading power, using efficient special committees, a well-designed education system was established in 1988. The George Soros Foundation offered extensive scholarship programmes for young professors to visit top US and European universities. More than 65 people participated in this programme in the period 1988-1991. The Central and Eastern European Teachers Programme, a Harvard University led consortium of five top US universities, hosted 15 university professors in 1992-1993. The workforce was ready to react to the new challenges posed by changes in the political system.

In addition to the favourable political and socioeconomic environment as external factors, there were four important internal aspects of success. First, there was a critical mass of professors and students who supported the changes. Although not without conflicts, the communist party, the trade unions and the young communist organisation (the power triangle) were also behind the reform. Second, efficient project organisation, using international evaluators, helped the capable, courageous people in hierarchical teams to develop the system. Corrections based on continuous feedback did not damage the principles of the reform. Third, a favourable financial situation assured a quiet background. Public financing increased in real terms, and there were new opportunities to generate extra income. Fourth, matrix organisation helped the venture-type new initiatives (such as the International Studies Centre) and the joining, emerging institutions (such as the National Management Education Centre) to operate profitably.

The third period, 2008-2013, is fairly controversial. It was marked by the economic crisis, coupled with imperfect governance, severe public budget cuts and a lack of charismatic leadership. The faculties became the main power centres, resulting in decision processes lacking transparency. Hungarian universities such as the CUB were occupied with the Bologna Process, one of the most criticised systems in Hungary. The centrally orchestrated process did not rely on entrepreneurship, innovation or fulfilling new ambitions. Underfinancing, especially in last two years, against a backdrop of increasing student numbers and higher own revenues, caused a lot of everyday problems. The number of students in higher education fell from 427,000 in 2004 to the present level of 320,000 . Correspondence education, especially courses offered in the evening, lost its student body. The intensity of competition increased, resulting in the 
increased popularity of national ranking, with the Corvinus University retaining a stable first place. Some programmes also achieved a positive evaluation in the Financial Times ranking. The university with the undisputed top position in Hungary is against entrepreneurship, which is badly needed in international competition. This is why this period is called a "would have been reform period".

\section{Conclusions}

Entrepreneurship is an important source of business, and some of the most successful universities have followed this principle. Global competition and the internationalisation of universities have forced the government and higher education institutions to look for new methods: concepts that might help the country and the university to be more successful. Theory and practice should be examined in parallel in order to find good solutions for specific situations and specific institutions. We argue that not only small and new universities, but also large, top, traditional universities can or should use an entrepreneurial orientation in conjunction with other orientations, such as market orientation. The growth imperative in business and economics also has an influence on higher education. Organic growth is not the only way of expansion, as we have learned from mergers and foreign campus developments.

The Corvinus University of Budapest and its predecessors in the economics, business and social sciences area have undergone two influential reforms in their history. The research question was to determine whether these reforms and the present situation fit entrepreneurship indicators. The result might be surprising, but it is also thought provoking. The development of the market economy, the existence of capitalist society in the last 25 years in Hungary, has not resulted in one of its top universities being more entrepreneurial than it was before. Even though its domestic competitiveness has remained, the drive for international competitiveness is missing. In his recent work, Kornai (2014) argues about the polarities/differences of capitalism and socialism. Capitalism is dynamic and progressive, whereas socialism is slothful and imitative. The history of higher education in Hungary produces opposite examples as well.

The present paper is more conceptual, and future research should analyse more facts about the institutions that have undergone reform processes. The contrast of entrepreneurial and other higher education institutions could be combined with recently developed university mapping (U-Map) research. Mass versus elite higher education, internationalisation and demography, are the key areas that will determine future trends. Macro and micro level changes should be analysed hand in hand. 


\section{References}

Bahadir, S. C., Bharadwaj, S., \& Parzen, M. (2009). A meta-analysis of the determinants of organic sales growth. International Journal of Research in Marketing, 26(4), 263-275.

Clark, B. R. (1983). The Higher Education System. Berkeley: University of California Press.

Clark, B. R. (1998). Creating Entrepreneurial Universities. Organizational Pathways of Transformation. IAU Press Pergamon.

Coase, R. H. (1937). The Nature of the Firm, Economica, (in Hungarian: A vállalat természete). In $A$ vállalat, a piac és a jog (2004, Volume 4, November, 53-84 old.). Budapest: Nemzeti Tankönyvkiadó Rt.

Csáki C., \& Zalai, E. (1987). Képzéskorszerűsítési koncepció a Marx Károly Egyetemen (A concept of modernising the training of economists at the Karl Marx University of Economics). Gazdaság, 2o(2), 94-108.

Csáki, C. (2013). A modern közgazdászképzés alapjainak megteremtése egyetemünkön (Establishing the fundamentals of modern economic and business education at the Karl Marx University of Economics). In Matematikai Közgazdaságtan,: elmélet, modellezés, oktatás, Tanulmányok Zalai Ernőnek (pp. 417-526). Budapest: Müszaki Könyvkiadó.

Drucker, P. (1985). Innovation and Entrepreneurship, Practice and Principles. London: William

Heinemann Ltd.

Ennew, C., \& Fujia, Y. (2009). Foreign Universities in China: A Case Study. European Journal of Education, 44(1), 21-36

Fábián, I. (2012). Nemzetközi kihívások és lehetőségek a magyar felsőoktatásban (International Challenges and Opportunities in Hungarian Higher Education). In J. Berács, I. Hrubos, \& J. Temesi (Eds.), "Hungarian Higher Education 2011" Domestic discussion questions - international trends, NFKK Füzetek 9, page 151-157.

Gould, E. (2003). The University in a Corporate Culture. Yale University

Hammond, K. L., Webster, R. L., \& Harmon, H. A. (2006). Market Orientation, Top Management Emphasis, End Performance within University Schools of Business: Implications for Universities.

Journal of Marketing Theory and Practice, 14(1), 69-85

Hrubos, I. (Ed.) (2004). A gazdálkodó egyetem (The Economic University). Budapest: Új Mandátum Kiadó.

Hrubos, I. (2006). A felsőoktatás intézményrendszerének átalakulása - Válogatott tanulmányok (Transformation of the institutional system of higher education - selected essays). Budapest: Aula. Kornai, J. (1992). The Socialist System: The Political Economy of Communism. Oxford: Clarendon Press. Kornai, J. (2014). Dynamism, Rivalry, and the Surplus Economy. Two Essays on the Nature of Capitalism. Oxford: University Press.

Nagy, G., \& Berács, J. (2012). Antecedents to the Export Market Orientation of Hungarian Higher Education Institutions, and their Export Performance Consequences. Journal of Marketing for Higher Education, 22(2), 231-256. 
Nelles, J., \& Vorley, T. (2008). Entrepreneurial Architecture in UK Higher Education Institutions: Consolidating the third mission, Paper presented at the $25^{\text {th }}$ Celebration Conference on Entrepreneurship and Innovation - Organizations, Institutions, Systems and Regions, Copenhagen, CBS, Denmark, June 17-20, 2008.

Pantic, N. (2012). Teacher Education Reforms between Higher Education and General Education Transformations in South-Eastern Europe: Reviewing the Evidence and Scoping the Issues. CEPS Journal, 2(4), 71-90.

Saloner, G. (2013). Reinventing Management Education: A Work in Progress. Stanford Business, Spring 2013, p. 1.

Schumpeter, J. A. $(1968,1926)$. The Theory of Economic Development, $8^{\text {th }}$ edition. Harvard University. (In Hungarian: A gazdasági fejlődés elmélete, Budapest: KJK, 1980).

Shin, J. C., Toutkoushian, R. K., \& Teichler, U. (Eds.) (2011). University Rankings - Theoretical Basis, Methodology and Impacts on Global Higher Education. Springer.

Vlasceanu, L., \& Hancean, M.-G. (2012). Policy and Prediction: The Case of Institutional Diversity in Romanian Higher Education. CEPS Journal, 2(4), 53-70.

Zgaga, P. (2003). Reforming the Universities of South-East Europe in View of the Bologna Process. Higher Education in Europe, 28(October), 251-258.

\section{Biographical note}

JózSEF Berács is a professor of marketing at Corvinus University of Budapest (CUB) and at Babes-Bolyai University in Cluj-Napoca. He was the founder director of the International Studies Center, the English language program of the Corvinus University of Budapest 1990-2007. He served as President of European Marketing Academy (EMAC) in 2006-2008. Since 2009 he is EMAC fellow. His research interest is marketing strategy, marketing in emerging (transition) economies, market orientation, especially in the process of internationalization of higher education. He is executive-director and founder of the Center for International Higher Education Studies (CIHES) at the CUB. 